\title{
PENINGKATAN KUALITAS PEMBELAJARAN DENGAN MODEL PROBING PROMPTING Di SMP Mangunharjo Tugumulyo Musi Rawas
}

\author{
Ahmad Taufik \\ ahmadtaufik201902@gmail.com \\ STAI Bumi Silampari Lubuklinggau Sumatera Selatan \\ Khadafi Ramandhani \\ khadafiramadhani1211@gmail.com \\ STAI Bumi Silampari Lubuklinggau Sumatera Selatan
}

\author{
Ahmad Budiyono \\ onobudi.stituw@gmail.com \\ STIT Al-Urwatul Wutsqo Jombang
}

\begin{abstract}
:
The reality of the arrangement of Islamic religious education subjects has an important function as well as appreciating strategies regarding educational events at every level in educational attainment. However, the capacity of the reality of the time period in the field of Islamic religious education which is held in public schools still gets serious attention where problems and criticisms occur from various parties. Naturally, overcoming the form of shortcomings and weaknesses will practice Islamic religious education subjects in the school environment, at least through the path of manifestation towards the path of change. Therefore, it requires a policy study or a specific study according to the commitment called the reconstruction of Islamic religious education subjects. This study has a purpose, namely to determine the improvement of the quality of learning with the Probing Prompting model in Islamic religious education subjects for students of SMP Mangunharjo Tugumulyo Musi Rawas. This type of research is CAR participants. The place of this research is students at SMP Mangunharjo Tugumulyo Musi Rawas. The implementation time of this research is in the Odd semester 2020/2021 for Islamic religious education subjects. This study carried out several stages in its research, including: monitoring, results, evaluation and reflection. Data analysis technique in the form of quantitative description. the conclusions of this study show: 1). The learning model with the probing prompting model can improve the quality of learning for Islamic religious education subjects, it can be seen from the level of student activity, and test results. 2). Students like this learning model because it makes them always active in learning.
\end{abstract}

Keywords: Learning, Probing Prompting, Musi Rawas 


\section{Pendahuluan}

Tuntutan gejala perubahan yang melekat dari revolusi industri 4.0 dengan berbagai aspek-aspek dalam kegiatan roda kehidupan bagi manusia. Rohman mengatakan terkait memasuki era disrupsi bagian poin yang menjadi sorotan dimana masa menimbulkan banyak hal apalagi ganggu-gangguan sebab banyak sudah terjadi perubahan dengan berbagai macam-macam yang menjadi permasalahan di lingkungan masyarakat, termasuk munculnya perubahan paradigma ataupun visi sisi ganggu-gangguan dunia termasuk banyak hal kejadian langka mengenai segala isinya. Salah satu bentuk perubahan tentang cara memperbaiki kegiatan penanggulangan perencanaan sumber daya manusia yang terukur.

Sewajarnya berbagai peran menjadi dasar pengauatan mengenai modal suatu bangsa mensinergis pembangunan Indonesia, dasar ini mempunyai kesinambungan analisis peran akibat lingkungan sekolah dengan pola proses mencetak sumber daya manusia secara sistematis. Untuk itu meningkatan kualitas pembelajaran saat sinergis elemen-elemen mendasar lingkungan sekolah menjadi komposisi perhatian serius. Pendidik khususnya bagi guru bisa mentransformasi diri guna mengikuti proses kompetensi sehingga lingkungan sekolah dapat menghasilkan sumber daya manusia mumpuni dalam kreativitas. ${ }^{1}$ Guru mampu kemandirian menyesuaikan pribadi dengan adanya berbagai corak perubahan apalagi saat era revolusi industri 4.0. Pola pembelajaran berlangsung kini tak cukup menggunakan standar kegiatan pembelajaran yang lama ataupun tidak menyesuaikan model pembelajaran dalam pembaharuan. Oleh sebab itu, guru mahir kompetensinya supaya dapat menguasai pembelajaran sesuai pengaruh teknologi zaman.

Salah satu dominan tentang penguasaan kompotensi mengurangi ketertinggalan serta ditingkatkan dapat praktek secara benar ihwal perencaan pengajaran ideal. Guru dapat memiliki peran sebagai motivator, dan dapat keleluasaan kepada para siswa dalam transfer keilmuan sesuai cara gaya belajar yang berbeda. ${ }^{2}$ Model pembelajaran memakai cara konvensional dirubah, dimana titikberat terhadap output siswa difungsikan dengan mencari, menggali serta dialogis analisis mengenai macam-macam materi pembelajaran supaya para siswa aktif dalam pengembangan potensi yang dimiliki dan bisa mempunyai prestasi. Menurut Barry bisa mengaitkan bahwa terjadi pembelajaran konvensional dimana kegiatan pembelajaran lama dijadikan pembiasaan guru saat berada di kelas dalam menginformasikan secara verbal.

Salah satu pemakaian model pembelajaran guna peningkatan jaminan mutu proses pembelajaran sangat dapat membuat para siswa aktif dimana model pembelajaran probing prompting dijalani oleh guru sesuai penguasaan atas pengetahuan dikombinasikan mutu proses pembelajaran. Model pembelajaran

\footnotetext{
1 Trianto, Panduan Lengkap Penelitian Tindakan Kelas (Classroom Action Research): Teori dan Praktik, (Jakarta: Prestasi Pustakaraya, 2011), 16.

2 Zainal Aqib, Penelitian Tindakan Kelas, (Bandung: Yrama Widya, 2009), 40.
} 
yang dipakai probing prompting dimana guru ataupun para pendidik bisa menyajikan rangkaian dengan bentuk soal pertanyaan sifatnya menuntun atau menggali capaian materi kegiatan-kegiatan pembelajaran secara berlangsung. ${ }^{3}$ Model pembelajaran tersebut membuat menjadi siswa lebih aktif, beberapa siswa mempunyai materi disertai analisis jawaban ketika guru berusaha menjawab atas apapun yang dipertanyakaan oleh macam siswa.

Berdasar dengan latar belakang masalah, secara jelas dirumuskan masalah antara lain: Apakah dengan penerapan model pembelajaran Probing Prompting berguna dalam meningkatkan mutu suatu pembelajaran pada mata pelajaran pendidikan agama Islam? Penelitian ini memiliki tujuan supaya mengetahui apakah dengan penerapan Probing Prompting dalam meningkatkan mutu suatu pembelajaran mata pelajaran pendidikan agama Islam. Hasil penelitian ini secara teoritis digunakan dalam mempertimbangkan sistem penerapan model pembelajaran bagi guru guna mengusahakan atau merangkai sistem-sistem meningkatkan mutu pembelajaran.

\section{Metode Penelitian}

Penelitian ini bertujuan agar mampu menjelaskan dengan pendeskripsikan tentang Probing Prompting dalam meningkatkan mutu suatu pembelajaran mata pelajaran pendidikan agama Islam di SMP Mangunharjo Tugumulyo Musi Rawas dan bagaimana upaya guru dalam menggunakan model pembelajaran Probing Prompting di SMP Mangunharjo Tugumulyo Musi Rawas. Penelitian ini menggunakan pendekatan kualitatif dengan jenis penelitian studi kasus. Metode pengumpulan datanya: observasi, wawancara dan dokumentasi. Teknik analisis datanya menggunakan model interaktif Miles dan Huberman yang meliputi reduksi data, penyajian data dan penarikan kesimpulan.

\section{Hasil Penelitian dan Pembahasan Model Probing Promting}

Penggunaan probing prompting mempunyai pengertian bahwa model pembelajaran dengan sajian-sajian dalam serangkaian bentuk pertanyaan bersifat menuntun dan mampu menggali potensi, sehingga dapat menjadi pembentukan proses dalam menggunakan berpikir supaya pengetahuan dan pengalaman bererapa siswa sesuai atas pengetahuan-pengetahuan baru dipelajari saat pembelajaran di kelas. ${ }^{4}$ Dalam pemakaian mengindikasi model-model pembelajaran mengajak para siswa berusaha menciptakan lingkungan aktif, atau bisa tanya jawab sendiri dengan cara guru menunjuk para siswa, hingga komponen individual dari siswa melaksanakan proses partisipasi dengan sistem pembelajaran yang kondusif.

\footnotetext{
${ }^{3}$ M. Huda, Model-Model Pengajaran dan Pembelajaran Isu-Isu Metodis dan Paradigmatis, (Yogyakarta: Pustaka Pelajar, 2013), 28.

4 Arif Purnomo, dkk. Model Pembelajaran Ilmu Pengetahuan Sosial (IPS) Pada Materi Kontroversi (Controversy issue) di Sekolah Menengah Pertama (SMP) Kota Semarang. Universitas Negeri Semarang, Vol. 33 Nomor 1 Tahun 2016. Dalam jurnal pdf.
} 
Menurut Nurhamiyah, menjelaskan dengan istilah model probing prompting ialah mengaitkan berbagai ketrampilan memberi atas hakikat penguatan, fungsi mendasar sebuah pengetahuan mampu menimbulkan watak positif serta melibatkan secara aktif bagi para siswa guna mengolah macammacam kegiatan pembelajaran. Probing prompting mengartikan dengan pola pemilihan pembelajaran non konvensional efektif dengan kajian sejumlah bentuk pertanyaan bisa menyusun dengan olah cipta seorang guru. ${ }^{5}$ Dalam proses pembelajaran, pemakaian model probing prompting dapat menyisakan sifat tegang, ada juga kepastian yang bisa diupayakan oleh banyak guru dengan menjalin tetap ramah memberi bentuk soal disajikan atas berbagai pertanyaan dan mampu menghargai semua jawaban dari sisa soalyang ada.

\section{Langkah proses pembelajaran Probing prompting diantaranya:}

1) Guru menghadapkan para siswa dalam situasi yang baru, misalnya guru membeberkan gambar, dengan bentuk rumus, atau bisa pula situasi lain yang mengandung permasalahan yang konkrit. ${ }^{6}$

2) Guru mengajukan bentuk persoalan disesuaikan ketetapan tujuan dari mutu pembelajaran khusus atau bisa pula indikator berbagai macam siswa.

3) Menunggu penciptaan lingkungan sesaat memberi kesempatan para siswa bisa mengajak mereka dapat merumuskan jawaban atau pun siswa dapat merangkai diskusi kecil.

4) Menunjuk salah satu siswa untuk menjawab pertanyaan.

5) Jika jawaban secara tepat, maka guru dapat minta tanggapan para siswa lain kaitan langkah-langkah jawaban guna meyakinkan kepada seluruh siswa agar terlibat kegiatan-kegiatan yang sedang berlangsung. Namun, jika siswa dapat mengalami kesulitas atas bentuk jawaban atau yang dijawab kurang tepat, atau siswa mampu berdiam diri, maka tugas guru bisa mengajukan soal pertanyaan lain dimana jawaban disini dapat menjadi petunjuk jalan ketika siswa akan menyelesaian berbagai jawaban. Kemudian para guru bisa memberi bentuk soal dalam pertanyaan agar menuntun siswanya mampu mengolah pikiran tingkat yang lebih tinggi, sehingga kemampuan siswa dalam menjawab macam-macam pertanyaan sesuai banyaknya kompetensi dasar atau indikator kompetensi. Pertanyaan yang diajukan pada langkah ini diberikan kepada para siswa berbeda supaya capaian seluruh siswa terlibat langsung ketika terjadi kegiatan probing prompting.

6) Guru mengajukan berbagai pertanyaan akhir kepada siswa berbeda guna lebih menekankan atas indikator tersebut benar dengan kondisi secara pemahaman dengan indikasi seluruh siswa.

Kelebihan dan kekurangan model Probing Prompting kelebihan antara lain:1) Mendorong siswa memiliki pikir aktif. 2) Memberi kesempatan para siswa agar dapat menanyakan hal yang dianggap kurang jelas hingga guru dapat

\footnotetext{
${ }^{5}$ Rudy Gunawan, Pendidikan, (Bandung: Alfabeta, 2013), 43.

6 Rusman, Model-Model Pembelajaran: Mengembangkan Profesionalisme Guru, (Depok: Raja Grafindo Persada, 2010), 136.
} 
menjelaskan dengan kembali. 3) Perbedaan pendapat siswa diarahkan dalam metode diskusi. 4) Pertanyaan yang menarik guna memusatkan perhatian dari siswa. 5) Sebagai cara meninjau kembali bahan atas pelajaran terlampau. ${ }^{7}$ 6) Mengembangkan sifat berani dan ketrampilan perilaku siswa dalam menjawab dan mengemukakan pendapatnya. Kelemahan model pembelajaran probing prompting yaitu: 1). Dalam jumlah sisa yang banyak, tidak memungkinan atas cukup waktu memberi soal pertanyaan terhadap peserta didik. 2). peserta merasa takut, apalagi guru kurang mendorong siswa untuk bisa memiliki keberanian, seperti menciptakan suasana ketidakan tegang, melainkan guru dapat akrab. 3). Tidak mudah membuat pertanyaan disesuaikan berbagai tingkatan mengolah pikir dan mudah dipahami. 4). Waktu dapat terbuang jikalau tidak mampu menjawab pertanyaan kepada siapa saja dengan analogis sampai dua atau tiga orang. 5) Dalam jumlah peserta yang banyak, tidak memungkin cukup waktu memberi soal pertanyaan kepada tiap peserta.6). Dapat menghambat pemikiran kepada beberapa siswa bila kurang pandai membawakan pemikiran. ${ }^{8}$

\section{Pendidikan Agama Islam}

Pendidikan agama Islam (PAI) di sekolah belum memenuhi keingin tahuan tuntunan secara syariat umat Islam, terutama PAI apa yang diajarkan di lingkungan sekolah umum. Mengingat alamiah kendala dihadapi oleh guru maupun para siswa, maka sewajarnya memerlukan kebijakan pegangan agar dapat membina pendidikan agama Islam secara menyeluruh. ${ }^{9}$ Semua ini mengacu pengusahaan penerapan strategi sesuai perencanaan strategis kebijakan dalam kategori umum dituangkan Direktorat Jendral Pendidikan Agama Islam Departemen Agama, yakni mampu menjalankan peningkatan mutu secara khusus pendidikan agama Islam di lingkungan sekolah umum. Peningkatan mutu itu sendiri dibeberkan kemajuan atau capaian jelas kendali kualitas hasil pembelajaran dari pendidikan agama Islam kepada para siswa yang mengikuti pendidikan secara rajin saat berada di kelas. ${ }^{10}$ Mutu itu sendiri sebetulnya tujuan yang diinginkan guna memenuhi kualitas dari umat Islam sendiri.

Dalam pemenuhan yang terjadi, tatkala materi dari pendidikan agama Islam di lingkungan sekolah umum masih belum memenuhi keinginan sesuai arahan dan perilaku islami. Contoh mendasar, jikalau para guru memberi pendidikan agama Islam kepada para siswa, sudah tentu keinginan dari beberapa siswa supaya mereka tidak hanya memahami tetapi juga mereka dapat praktik penerapan aturan ajaran Islam baik kategori pokok untuk diri sendiri maupun kategori dalam sisi masyarakatan. Karena materi kaitan pendidikan agama Islam

7 Aris Shoimin, 68 Model Pembelajaran Inovatif Kurikulum 2013, (Yogyakarta: Ar-Ruzz Media, 2014), 34.

${ }^{8}$ Suyatno, Menjelajah Pembelajaran Inovatif, (Sidoarjo: Masmedia Buana Pustaka, 2009), 98.

9 Abdurrahman An-Nahlawi, Pendidikan Islam di Rumah, Sekolah, dan Masyarakat, (Jakarta: Gema Insani Press, 2006), 56.

${ }^{10}$ Rochiati Wiriatmadja, Metode Penelitian Tindakan Kelas, (Bandung: Remaja Rosdakarya, 2008), 18. 
bukan hanya memperhatikan aspek kognitif, ketergantungan pemberlakuan kebaikan dalam sikap dan ketrampilan para siswa sangat menjadi prioritas. ${ }^{11}$

Siswa jikalau mendapatkan nilai kognitif dengan hasil bagus, belum bisa dikatakan sudah berhasil jika nilai sikap dan ketrampilan siswa kurang. Begitu pula sebaliknya, jikalau siswa mempunyai sikap dan ketrampilannya bagus sekali tetapi kognitifnya kurang, belum bisa dikategori dengan capain fungsi pendidikan agama Islam itu berhasil. Inilah yang belum memenuhi berbagai keinginan umat Islam sendiri. Contoh yang direkomendasikan, hampir sebagian umat Islam menginginkan agar para siswa jelas membaca ayat al-Quran, namun fungsi dan bimbingan oleh orang tua sangat mengandalkan kepada pihak sekolah agar anak baca al-Quran secara lancar. Sekolah nampaknya belum memberi harapan itu karena terbatas dengan pembagian alokasi waktu atau jam pelajaran agama Islam di lingkungan sekolah umum.

Pelaksanaan pendidikan agama Islam di sekolah umum banyak tantangan yang dialami, karena ketercapaian formal penyelenggaraan pendidikan ajaran Islam di sekolah hanya 2 jam pelajaran per minggu. Jika sebatas hanya memberi pengajaran fungsi Islam menekankan aspek kognitif konkrit, memungkinkan bagi guru melaksanakannya, tetapi jika memberi pengetahuan pendidikan sebatas analogis meliputi tidak hanya kognitif juga mengerti hasil sikap dan ketrampilan, para guru akan mengalami kesulitan saat mengikutinya.

Pelaksanaan pendidikan Islam sekolah umum siswa sangat mengalami minim jikalau mengandalkan pendidikan agamanya sesuai dari jam regular sekolah. Kecuali bagi para siswa tinggal di daerah wujudnya penemuan madrasah diniyah atau pesantren, biasa mereka mengikuti pendidikan Islam di sekolah umum tidak banyak menghadapi masalah-masalah atas gejala proses, karena mereka mengikuti pembelajaran sekolah dan bisa pula dapat belajar pendidikan Islam di madrasah diniyah atau pesantren. Tetapi kondisi semacam ini pada masa sekarang sudah sulit dijumpai. Ada beberapa kemungkinan resiko bagi para siswa, dimana para siswa dapat mengikuti belajar materi Islam dari sisa waktu pengalaman beberapa orang tuanya. Siswa dapat belajar isi sesuai syariat Islam dengan mengundang ustadz ke rumahnya. Ada pula masih mengerti siswa yang hanya mengandalkan pendidikan Islam dari lingkungan sekolah tanpa mendapati sisi tambahan belajar anjuran sisi agama dari tempat lain. ${ }^{12}$

Padahal dalam materi pendidikan agama Islam sudah semestinya penguasaan bagi para siswa, sebagaimana kaitan kategori pengetahuanpengetahuan agama, bisa mengalami penanaman aqidah, praktik proses ibadah, pembinaan perilaku atau yang dalam undang-undang disebut dengan pembinaan akhlak mulia. Kendala atau tantangan ketika terjadi terlaksana mengaitkan pembelajaran agama Islam di lingkungan sekolah indikasi waktu sangat terbatas,

11 M. Somantri, Menggagas Pembaharuan Pendidikan, (Bandung: Remaja Rosdakarya, 2001), 27.

12 Anwar Rasyid, Ilmu Pendidikan Islam: Teori dan Aplikasi, (Surabaya: TMP, 2011), 36. 
dengan pengelabuhan hanya 2 jam pelajaran per minggu. Menghadapi kendala ataupun beberapa tantangan, sungguh para guru menjalar sebagai ujung tombak proses pembelajaran di lapangan/sekolah, perlu merumuskan model pembelajaran guna mengimplementasikan macam-macam kurikulum, khusus kaitan penjajakan kurikulum mikro pada kurikulum tuntunan ajaran Islam di sekolah.

Melalui pencapaian alur memakai ekstra kurikuler yangmana dilakukan di lingkungan sekolah formal menjadi bagian salah satu cara metodologi oleh sekian banyak guru guna menambahkan pemahaman tentang pembelajaran pendidikan agama Islam konkret. Sedangkan penerapan ekstra kurikuler terlaksana saat sekolah efektif, bisa diadakan saat beberapa siswa di kelas maupun mereka di mushala. Bisa juga adanya kesepakatakan di rumah atau tempat sesuai persetujuian bersama. Waktu belajar tentunya di luar lingkungan sekolah formal agar sama-sama memberi efek positif bagi siswa. Cara ini butuh tambahan sarana fasilitas, kegiatan pendukung waktu, serta ketersediaan tenaga guru, yang paling mendominasi berupa kebutuhann pembiayaan, ini menjadi tantangan guru tidak hanya ikut mengajar; juga menghiraukan fungsi nilai semangat dakwah menyebarkan pengetahuan esensi agama sejauh mana manusia berpijak tanpa rasa putus asa. Untuk itu koordinasi ataupun saling kerja sama kesinambungan menuju kegiatan bersama baik guru dan para orang tua siswa. ${ }^{13}$ Samsul Nizar mengatakan esensi makna pendidikan agama Islam keterkaitan koordinasi orientasi saat belajar berlangsung mengenai pengetahuan esensi agama hal mengaitkan tugas mulia manusia sebagai khalifah. Karena itu, tak pelak negeri ini menjumpai kegiatan tiap orang notabene kategori mengetahui kejeniusan tentang nilai dasar sebuah agama, akan tetapi perilaku atau kebiasaan sehari-hari kurang relevan terkait contoh nilai ajaran agama yang sudah diketahuinya. ${ }^{14}$

Persoalan materi yang terkandung dalam pemahaman pendidikan agama menitikberatkan sistem konsentrasi pada persoalan keteoritisan agama kecenderungan kepemilikan sifat kognitif, adanya kurang concern terhadap persoalan-persoalan komponen pasti lini kehidupan dengan cara bisa mengubah pengetahuan nilai agama kognitif menjadi nilai kebersamaan mengenai "makna" dan "nilai" disini bisa diinternalisasi penuangan diri para siswa secara terlewat rutinitas berbagai cara, sarana internalisasi maupun terbentuk momentum fungsi skala forum. ${ }^{15}$ Kesinambungan inti pengertian dari nilai objektif pendidikan Islam maupun acuan sisi agama Islam dimengerti sebagai bentuk usaha dari komunitaskomunitas muslim hakiki mampu mengajak kebiasaan dalam komunitasnya,

\footnotetext{
13 Abd. Chayyi Fanany, Ilmu Pendidikan Islam, (Surabaya: Taruna Media Pustaka, 2010), 8.

14 Samsul Nizar dan Muhammad Syaifudin, Isu-Isu Kontemporer tentang Pendidikan Islam, (Jakarta : Kalam Mulia, 2010), 240.

15 Muhaimin, Pengembangan Kurikulum Pendidikan Agama Islam di Sekolah, Madrasah dan Perguruan Tinggi, (Jakarta: Rajawali Press, 2012), 24.
} 
untuk mengetahui pendalaman sirah pengetahuan Islam titik berat sumber referensi utama berasal dari ketersediaan mutiara al- Qur'an dan Sunnah. ${ }^{16}$

Seolah-Olah persoalan yang bisa dijangkau berasal pendidikan agama Islam hanya berkutik mengenai urusan kejadian-kejadian ritual maupun spritual, sementara gejala akibat kehidupan ekonomi, politik, seni-budaya, globalisasi kebermaknaan dan teknologi serta seni, dan sebagainya dianggap urusan dunia saja adalah tendensi akhir garapan tujuan tiap pendidikan non-agama. Pandangan dikotomis penyebab kesimpulan dualisme menjalar sistem roda keterpihakan pendidikan. Istilah filosofis antara pendidikan agama dan pendidikan umum, sebenarnya muncul adanya paradigma dikotomis tersebut. Maka kesejajaran dikotomis harus diterangkan dan mendapat kontribusi nyata dalam kehidupan. ${ }^{17}$

Proses integrasi yang sudah terjadi baik pengetahuan agama Islam dan kontribusi dari ilmu umum merupakan cara mengusahakan atau dapat mengembalikan keterpihakan fungsi teori pendidikan kepada pengetahuan agama, maka sistem anjuran yang dihasilkan oleh nilai pendidikan diharapkan mampu kesinambungan adanya integrasi sebuah nilai esensi dalam ilmu pengetahuan, nilai ketersambungan agama dan etik, dan bisa melahirkan manusia yang konkret penguasaan dan penerapan sebuah ilmu pengetahuan, teknologi, agar memiliki kematangan profesional serta fungsi hidup berasal dari kepastian nilai agama. Paradigma tersebut tampaknya mulai dirintis dan dikembangkan yang berada di lingkungan madrasah melalui identitas deklarasi sebagai tolak ukur sekolah umum secara khas menurut tuntunan agama Islam. Jelasnya pengetahuan pendidikan, seperti pendapat Moh. Roqib, bahwasannya bukan hanya hasil kerja secara mekanis, melainkan pula gejala mengenai proses panjang atau keterpihakan agung agar kemampuan mengembalikan dan cara meningkatkan potensi maupun kondisi moral utama dalam sejarah manusia. ${ }^{18}$

Guru difungsikan dalam pemenuhan kesinambungan konsisten komponen pendidikan yang mengakomodir banyak peran dan rencana-rencana inti dalam strategis keilmuan. Menurut Zakiyah Darajat, ditemukan dalam kutipan Muhammad Fathurrohman, definisi guru ialah pendidik profesional disebabkan implisit guru secara suka rela mengabdikan dirinya sebagai peran dapat menerima maupun dapat memikul sebagian tanggung jawab dalam menjalan karir pendidikan atas keterpihakan mereka dalam membersamai dengan orang tua. ${ }^{19}$ Adapun guru pendidikan agama Islam sejatinya ketika guru juga mengikuti macam-macam kegiatan pendidikan sesuai arahan dan koordinasi nilai Islam, dimana pengupayaan tugas normatif membantu seorang diri atau bisa pula sekelompok orang (para siswa) agar manfaat mengembangkan pandangan hidup

\footnotetext{
16 Anshori LAL, Transformasi Pendidikan Islam, (Jakarta : Gaung Persada Press, 2010), 20.

17 AbuddinNata,Paradigma Pendidikan Islam,(Jakarta:Grasindo, 2001), 2.

18 Moh Roqib, Ilmu Pendidikan Islam: Pengembangan Pendidikan Integratif di Sekolah, Keluarga dan Masyarakat, (Yogyakarta: LKis, 2009), 87.

19 Muhammad Fathurrohman dan Sulistyorini, Meretas Pendidikan Berkualitas dalam Pendidikan Islam, (Yogyakarta: Teras, 2012), 20.
} 
koridor Islam (sebagaimana bisa memaknai atau memanfaatkan roda fungsi sebuah perjalanan hidup menyesuaikan ajaran-ajaran maupun pendalaman nilai Islam), mampu bersikap lingkungan tata cara Islam, yang dimanifestasi dalam ketrampilan hidup kebiasaan dalam rumah tangga. ${ }^{20}$

Mata pelajaran pendidikan agama Islam dengan jumlah siswa sebanyak 30 orang di SMP Mangunharjo Tugumulyo Musi Rawas. Pada Siklus I dilaksanakan dua kali pertemuan, selama 3 jam pelajaran (6x 45 menit) yang diikuti 30 siswa. Kegiatan pembelajaran diawali apersepsi dengan mengingatkan kembali materi pertemuan sebelumnya. Kemudian kegiatan inti dengan menyampaikan materi berlangsung selama 40 menit. Pada pertemuan ini, para siswa diajak mampu ikut kerjasama. Pada proses pembelajaran siklus I persentase kerja siswa sebesar 62,5\%, siswa masih belum terbiasa untuk belajar dengan aktif. Hal ini dibuktikan dari hasil pengamatan, siswa masih belum bisa mengikuti proses pembelajaran dengan baik, masih ada siswa yang bercanda, dan adapula siswa masih belum terbiasa pengenalan pembelajaran model probing-prompting ketika materi disampaikan di kelas. Pada hasil tes siklus 1 nilai rata-rata sebesar 64,90 dengan nilai tertinggi 82 sedangkan nilai terendah 45. Dalam siklus I ini presentasi ketuntasan belajar siswa 47,5\%, yang tidak lulus 52,5\%. Hasil refleksi pada Siklus I masih belum tepenuhi, sedangkan kriteria ketuntasan minimal yang harus dpenuhi ialah 75\%, dan diketemukan bahwa hasil pengamatan keaktifan dari siswa masih juga adanya penyesuaian pengenalan pembelajaran model probing prompting, selanjutnya penelitian ini dilanjutkan ke siklus II.

Proses pelaksanaan siklus II dilaksanakan selama dua kali pertemuan (6x45 menit). Pada siklus II peneliti harus bisa mengendalikan kondisi kelas agar dapat merangsang para siswa agar mereka terlibat aktif atas penyampaian model pembelajaran probing prompting. Pada proses pembelajaran siklus II persentase kerja siswa sebesar $81,5 \%$, hal ini sebagai wujud dasar kepentingan sebagai hasil pengamatan menunjukkan para siswa sudah mempunyai modal keberanian dalam menjawab bentuk pertanyaan yang diajukan oleh peneliti. Hasil tes siklus II juga menunjukkan peningkatan nilai rata-rata menjadi 75,05 dengan nilai tertinggi 90, sedangkan nilai terendah 45. Dalam siklus II ini presentasi ketuntasan belajar siswa $82 \%$.

Pembahasan penelitian ini diperoleh dari hasil penelitian dan catatan yang diperoleh selama penelitian berlangsung. Dari hasil pengamatan pada siklus I secara umum siswa kurang terlibat aktif. Siswa mengalami kesulitan dalam mengeluarkan pendapatnya dimana para siswa belum mengerti model pembelajaran dengan pelaksaan model probing-prompting. Hasil belajar siswa yang diperoleh pada siklus I cukup baik. Nilai rata-rata hasil belajar 64,90 naik sebesar 21,9 poin dari nilai rata-rata sebelum penelitian yaitu sebesar 43,00. Persentase ketuntasan belajar 47,5\% naik $28 \%$ dari rata-rata hasil belajar sebelum menggunakan model pembelajaran probing-prompting 20\%, hingga indikator

20 Syamsul Ma'arif, Revitalisasi Pendidikan Islam, (Yogyakarta: Graha Ilmu, 2007), 128. 
belum tercapai. Dari hasil analisis ini juga perlu dilakukan siklus II, agar ada peningkatan hasil belajar siswa bagus.

Pelaksanaan pembelajaran dengan analogi model probing-prompting pada siklus II sudah telihat adannya peningkatan. Aktivitas siswa.mendapat nilai 81,5\% sudah termsuk dalam kategori baik. Dari hasil observasi, banyak diantara siswa sudah mampu mengikuti pembelajaran dalam model probing-prompting menunjukkan hasil baik. Hasil belajar siswa juga mengalami peningkatan dari hasil pembelajaran pada siklus I nilai rata-rata 64,90 meningkat 10.15 poin menjadi $75.05 \%$, sedangkan presentase ketuntasan dalam pembelajaran siklus I $47.5 \%$ menjadi $82 \%$ pada siklus II, naik 34.5 poin. Data lengkap nilai rata rata dan presentase ketuntasan dapat disajikan berturut turut sebagai berikut:

Table 1 Daftar hasil belajar siswa

\begin{tabular}{|l|l|l|l|}
\hline No & Hasil Belajar & Siklus I & Siklus II \\
\hline 1. & Nilai Tertinggi & 82 & 90 \\
2. & Nilai Terendah & 45 & 45 \\
3. & Nilai Rata-rata & 64,90 & 75,05 \\
4. & Ketuntasan \% & $47,5 \%$ & $82 \%$ \\
\hline
\end{tabular}

Dari daftar tabel diatas dapat diketahui hasil belajar siklus I ke siklus II tejadi peningkatan. Hasil belajar dalam siklus II sudah memenuhi ketuntasan belajar yaitu sebesar 82,\%, hingga penelitian tidak perlu lagi mengikuti dasar skenario keterlanjutan pada pada tahap siklus selanjutnya. 
Ahmad Taufik, Khadafi Ramandhani dan Ahmad Budiyono

Peningkatan Kualitas Pembelajaran...

\section{Diagram 1 Nilai rata-rata hasil belajar siswa}

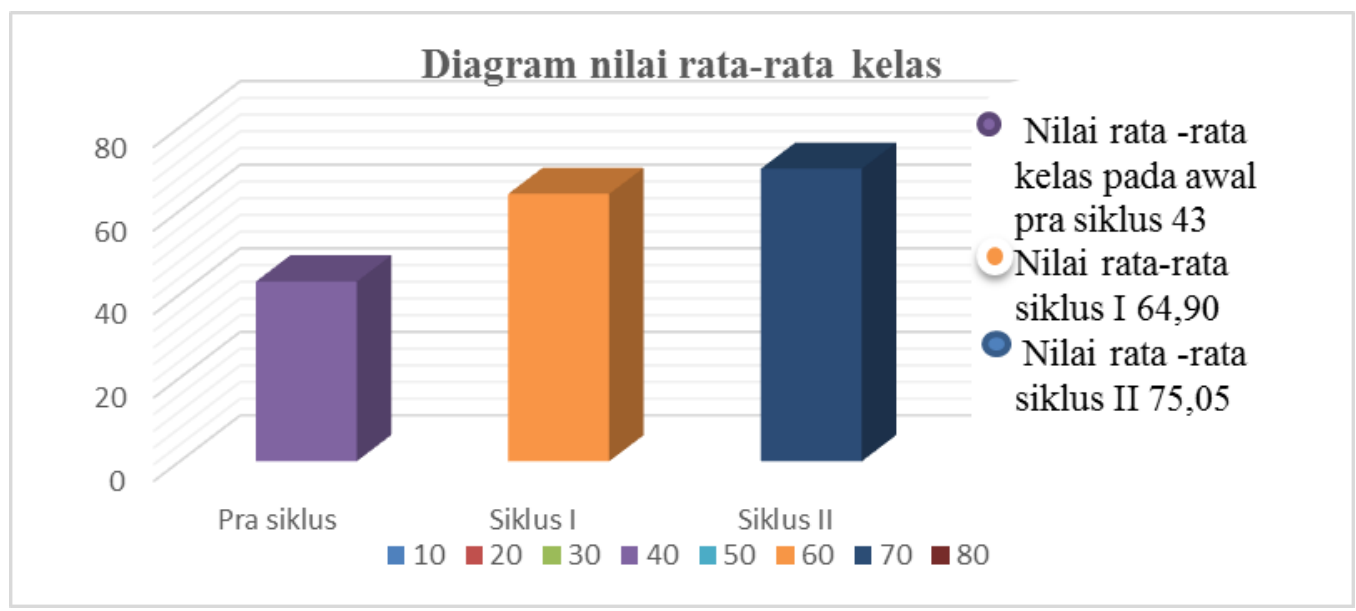

Diagram 2 nilai rata-rata presentase ketuntasan siswa

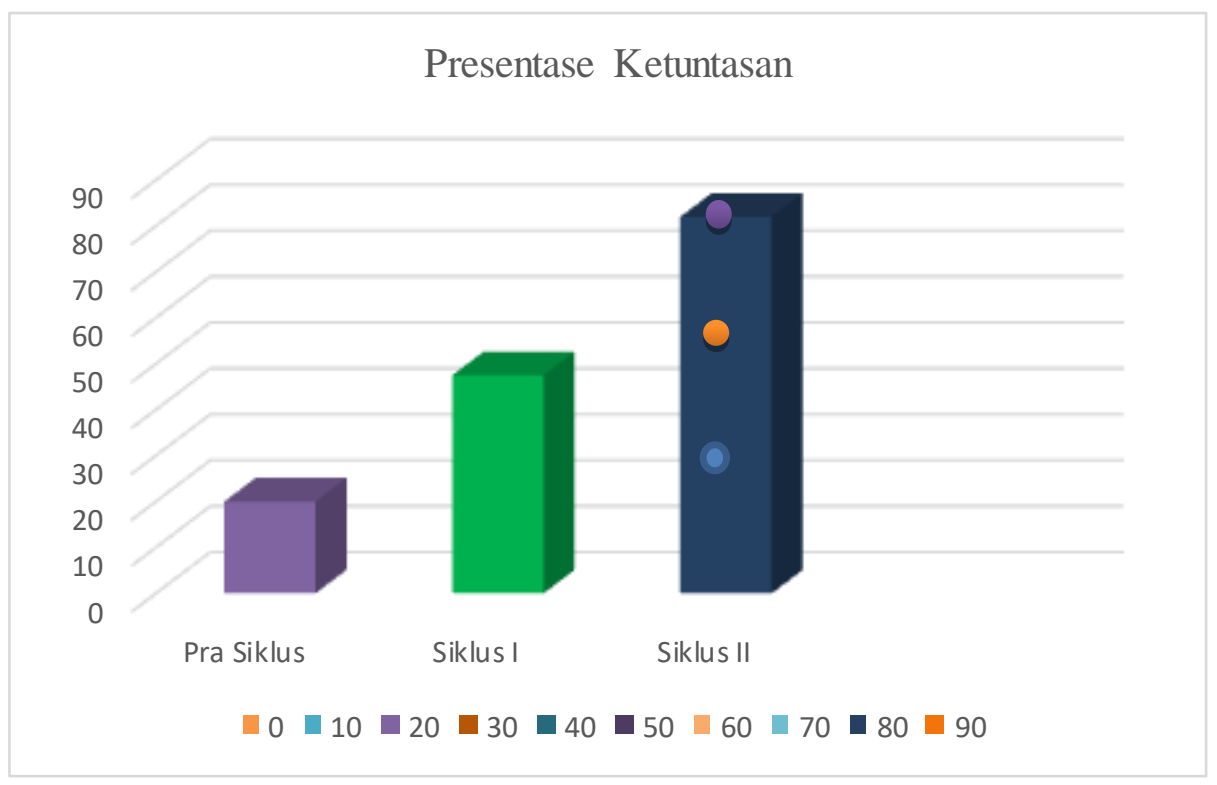

Dari hasil angket yang didapatkan oleh siswa secara setuju dengan model probing-prompting, setelah dibagikan mengajak beberapa siswa mata pelajaran pendidikan agama Islam, lalu berusaha menjalankan analisis dalam skenario penunjukan dari 30 responden, 26 responden (85\%) mempunyai respon yang baik terhadap proses pembelajaran, adapun mereka mulai tertarik dan antusias terhadap reaksi pembelajaran sesuai model probing prompting dalam mata pelajaran pendidikan agama Islam. Umumnya memakai pendekatan model probing prompting sebagai hasil pencapaian indikator sebuah penelitian dapat maksimal atau dianggap sudah tercapai. 


\section{Kesimpulan}

Fungsi pendidikan agama Islam menjelma dalam modal utama secara gamblang dikaitkan sistem pendidikan nasional berupaya meningkatkan kualitas manusia Indonesia seutuhnya, dapat memberi warna tersendiri ketika merekonstruksi materi-materi pendidikan agama Islam menjelma kaitan iman dan takwa (imtaq) sebagai cara upaya mengimbangi fungsi hasil ilmu pengetahuan dan teknologi (iptek) zaman global. Keseimbangan hasil manifestasi kemajuan iptek dan imtaq diharap mampu menghasilkan cendekiawan muslim selalu bertanggung jawab baik kehidupan dunia maupun akhirat.

Untuk itu, pendidikan agama Islam turut andil dalam manifestasi akademik tidak hanya ketersediaan lingkup pembenaran (context of justification), hal lain keterpihakan lingkup penemuan (context of discovery), visi kedalaman ilmu pengetahuan teknologi kesesuaian sekarang. Maka pendidikan agama Islam sejatinya dapat menginteraksi, tatanan interkoneksi maupun koordinasi dengan pelajaran lainnya. Hal kepentingan kategori ini bisa memposisikan pelajaran bidang pendidikan agama Islam keterkaitan celupan (sibghah) sebagaimana rona keterbimbangan pengetahuan teknologi diinginkan sangat bermanfaat terhadap kebahagiaan seluruh manusia.

Adapula pelajaran pendidikan agama Islam bisa diaplikasikan konten luas, karena menyangkut pengertian hakikat pendidikan sesuai arti pengetahuan saja, namun tak luput dengan pendidikan dalam arti praktek kepribadian. Pendidikan dalam arti pengetahuan tidak hanya jikalau tidak melibatkan pendidikan secara kepribadian, dimana keterpihakan pendidikan agama Islam tidak cukup melalui pengukuran bidang ranah kognitif saja, namun keterlibatan pengukuran bidang ranah afektif maupun psikomotorik. Dengan gejala tersebut diharapkan pelajaran pendidikan agama Islam bisa termanifestasikan sesuai berbagai desain misal penciptaan suasana religius di lingkungan sekolah umum. Pembelajaran yang terkelola memakai model probing-prompting ingin meningkatkan keaktifan para Siswa.

\section{Daftar Pustaka}

Aisyah, Siti. (2019). Strategi Peningkatan Kualitas Pembelajaran Pendidikan Agama Islam (PAI) Di SMPN 1 Lamongan. JMP Online, Vol. 3, No. 7, 1046 -1056. http://www.e-jurnalmitrapendidikan.com/index.php/e-jmp/article/view/590

Aqib, Zainal. Penelitian Tindakan Kelas. Bandung: Yrama Widya, 2009.

Fitriah, Raudoh \& Eka Naelia Rahmah. (2020). Peran Kepemimpinan Visioner Kepala Sekolah dalam Meningkatkan Kualitas Pembelajaran Pendidikan Agama Islam (PAI) di SMP Al-Hasra Depok. Qiro'ah : Jurnal Pendidikan Agama Islam, 10 (1), 123-144. https:/ / doi.org/10.33511/qiroah.v10n1.123-144

Gunawan, Rudy. Pendidikan. Bandung: Alfabeta, 2013.

Hartati, Meri \& Taufik, A. (2021). Pengaruh Penggunaan Smartphone Terhadap Interaksi Sosial anak pada TK Al-Karomah Kabupaten Lebong. Jurnal Zuriah: Jurnal Pendidikan Anak Usia Dini, Vol 2, No 2, 96- 118. http://journal.iaincurup.ac.id/index.php/paud 
Huda, M. Model-model Pengajaran dan Pembelajaran Isu-isu Metodis dan Paradigmatis. Yogyakarta: Pustaka Pelajar, 2013.

Priyanto, Adun. (2020). Pendidikan Islam Dalam Era Revolusi Industri 4.0. JPAI Journal, Vol. 6, No. 2, $80 \quad$ - 89.http://ejournal.uinmalang.ac.id/index.php/jpai/article/view/9072

Purnomo, Arif dkk. Model Pembelajaran Ilmu Pengetahuan Sosial (IPS) Pada Materi Kontroversi (Controversy issue) di Sekolah Menengah Pertama (SMP) Kota Semarang. Universitas Negeri Semarang, Vol. 33 Nomor 1 Tahun 2016. Dalam jurnal pdf.

Rusman. Model-Model Pembelajaran: Mengembangkan Profesionalisme Guru. Depok: Raja Grafindo Persada, 2010.

Shoimin, Aris. 68 Model Pembelajaran Inovatif Kurikulum 2013. Yogyakarta: Ar-Ruzz Media, 2014.

Suyatno. Menjelajah Pembelajaran Inovatif. Sidoarjo: Masmedia Buana Pustaka, 2009.

Somantri, M. Menggagas Pembaharuan Pendidikan. Bandung: Remaja Rosdakarya, 2001.

Taufik, Ahmad. 2013. Manajemen Sumber Daya Guru Bahasa Arab dalam Pengembangan Kinerja (Studi Kasus di SD Muhammadiyah Condongcatur Yogyakarta). Tesis Program Pascasarjana, Universitas Islam Negeri Sunan Kalijaga Yogyakarta.

Taufik, A. (2020). Strategi Pembelajaran Bahasa Arab Berbasis Internet. Edification Journal : Pendidikan Agama Islam,3(1), 57-72. https://doi.org/10.37092/ej.v3i1.208

Taufik, A., \& Hidayat, Nurul. (2021). Disiplin Siswa Perspektif Pendidikan Islam. Annuur Jurnal, Vol 11, No $2, \quad 76-\quad 84$. https://ejournal.staiamc.ac.id/index.php/annuur

Taufik, A., \& Novitasari. (2021). Penanaman Perilaku Sosial dari Lingkungan Sekolah SDN Giriyoso Kabupaten Musi Rawas. Jurnal Taujih: Jurnal Pendidikan Islam, Vol 14, No 2, 1- 15.

Trianto. Panduan Lengkap Penelitian Tindakan Kelas (Classroom Action Research): Teori dan Praktik. Jakarta: Prestasi Pustakaraya, 2011.

Suardipa, I Putu. (2020). Peran Desain Evaluasi Pembelajaran Untuk Meningkatkan Kualitas Pembelajaran. Widyacarya Journal,Vol.4No.2, 88-100. https://jurnal.stahnmpukuturan.ac.id/index.php/widyacarya/article/view/796

Wiriatmadja, Rochiati. Metode Penelitian Tindakan Kelas. Bandung: Remaja Rosdakarya, 2008.

Zidniyati. (2019). Penguatan Pendidikan Karakter di Sekolah Dasar di Era Revolusi Industri 4.0. Jurnal Tarbiyatuna : Kajian Pendidikan Islam, Vol. 3, No. 1, 4158. http://ejournal.iaiibrahimy.ac.id/index.php/tarbiyatuna/article/view/199 